\title{
ANALISIS KESULITAN BELAJAR SISWA BERKEMAMPUAN MATEMATIKA RENDAH BERDASARKAN GENDER
}

\author{
Septi Dariyatul Aini ${ }^{1 *}$, Moh. Zayyadi ${ }^{1}$, Anisatul Hasanah ${ }^{2}$ \\ Program Studi Pendidikan Matematika FKIP Universitas Madura, Indonesia \\ *E-mail: septi_math@unira.ac.id
}

\begin{abstract}
This study aims to fully describe the learning difficulties of students with low mathematical abilities in solving arithmatic division operations based on gender. This research is a descriptive qualtative research with research subjects consisting of 1 female student and 1 male student with low math ability in class IV-A SDN Bugih 1 Pamekasan with the test instrument for the comlpetion of the division count operations aninterviews. The results showed that on thr indicators of difficulty in understanding the concept, the results of the study learning difficulities in female subject (S1) and male subject (S2) in solving the division arithmetic operation, namely the two subjects did not know the concept of division as repeated subtraction. On the indicator of difficulty in applying the principle, the two subjects were unable to do the tiered division correctly because the wo principle of division to the long division. Whereas in the indicator of difficulty in solving verbal problems, the two subjects were unable to write down what wa known and what was asked of the story problem correclty.
\end{abstract}

Keyword : learning difficulties, low math skills, gender.

\section{PENDAHULUAN}

Dalam proses pembelajaran matematika, seringkali siswa dihadapkan kepada persoalan-persoalan yang menuntut adanya penyelesaian. Siswa dituntut untuk menanggapinya secara mental melalui kemampuan berpikir, khususnya mengenai konsep, atau prinsip dari suatu soal dan penyelesaiannya. Ini berarti aktivitas dalam belajar tidak hanya menyangkut masalah fisik semata, tetapi yang lebih penting adalah keterlibatannya secara mental yaitu aspek proses kognitif yang berhubungan dengan kecerdasan. Perkembangan kognitif menjadi sangat penting manakala anak akan dihadapkan kepada persoalan-persoalan yang menuntut kemampuan berpikir. Dalam belajar matematika di sekolah banyak menekankan kemampuan kognitif ini. Operasi hitung pembagian merupakan salah satu bagian dalam matematika yang mencakup berbagai materi yang dipelajari di SD. Kompetensi siswa dalam memahami operasi hitung pembagian merupakan prasyarat siswa untuk mampu atau kompeten dalam memahami materi selanjutnya. Sementara itu, setiap siswa memiliki tingkat intelektual yang berbeda-beda yang berakibat pada kemampuan matematika siswa yang berbeda pula dalam menyelesikan soal matematika termasuk pada operasi hitung pembagian. Perbedaan tersebut menyebabkan perbedaan penguasaan pemahaman konsep dan tahapan belajar yang dialami sebagai akibat dari berbagai faktor yang mempengaruhinya.

Masalah kesulitan belajar dihadapi oleh setiap jenjang sekolah. Sekolah dasar juga tidak luput dari masalah kesulitan belajar. Kesulitan belajar bisa terjadi pada semua siswa baik laki-laki ataupun perempuan. Hal ini juga terjadi SDN Bugih 1 Pamekasan, dimana siswa kelas IV-A SDN Bugih 1 Pamekasan mengalami kesulitan belajar pada materi

\footnotetext{
${ }^{1}$ Dosen Pendidikan Matematika Universitas Madura.

${ }^{2}$ Mahasiswa Pendidikan Matematika Universitas Madura
} 
operasi hitung pembagian. Sesuai dengan hasil observasi dan informasi dari guru SDN Bugih 1 Pamekasan, siswa kelas IV-A masih banyak yang mengalami kesulitan dalam memahami dan menyelesaikan soal matematika khususnya pada operasi hitung pembagian. Dari 22 siswa di kelas IV-A SDN Bugih 1 Pamekasan, hanya 25\% siswa yang sudah memahami dan dapat menyelesaikan soal materi operasi hitung pembagian dan 75\% siswa masih sulit memahami dan belum bisa menyelesaikan soal operasi hitung pembagian. Ini menunjukkan bahwa masih banyak siswa yang memiliki kesulitan dalam menyelesaikan soal operasi hitung pembagian.

Salah satu faktor yang dapat mempengaruhi hal tersebut karena kemampuan matematika siswa yang rendah. kemampuan adalah kapasitas seorang individu untuk melakukan beragam tugas dalam suatu pekerjaan, dan merupakan bakat yang melekat pada seseorang untuk melakukan suatu kegiatan secara fisik dan mental yang ia peroleh sejak lahir $[10,15,16]$. Berdasarkan pendapat kedua ahli tersebut, dapat disimpulkan bahwa kemampuan matematika adalah kapasitas seorang individu untuk melakukan beragam tugas dalam pelajaran matematika. Sedangkan kemampuan matematika rendah adalah tingkat kemampuan siswa yang rendah dalam melakukan beragam tugas dalam pelajaran matematika.

Gangguan dan kesulitan dalam kegiatan belajar mengajar itu wajar dan harus dipecahkan, bukan dihindari. Dengan dilakukannya analisis kesulitan belajar, diharapkan dapat menemukan penyebab kesulitan siswa dalam memahami dan menyelesaikan soalsoal matematika pada materi operasi hitung pembagian. Sehingga diharapkan kedepannya siswa tidak lagi menemui kesulitan dalam memahami dan menyelesaikan soal-soal matematika, terutama materi operasi hitung pembagian. Selain itu, dengan mengetahui kesulitan belajar siswa akan mempermudah mengambil tindakan selanjutnya untuk mengatasi masalah yang dialami siswa.

Menurut Cooney terdapat tiga indikator kesulitan belajar siswa, yang sebagaimana disajikan pada Tabel 1. sebagai berikut.

Tabel 1. Indikator kesulitan belajar siswa dalam menyelesaikan soal

\begin{tabular}{rll}
\hline \multicolumn{1}{c}{ No } & \multicolumn{1}{c}{ Indikator } & \multicolumn{1}{c}{ Terjemahan } \\
\hline 1. & $\begin{array}{l}\text { Kesulitan dalam mempelajari } \\
\text { konsep }\end{array}$ & $\begin{array}{l}\text { Siswa sulit dalam mempelajari konsep } \\
\text { matematika dalam menyelesaikan soal }\end{array}$ \\
\hline 22. & $\begin{array}{l}\text { Kesulitan dalam menerapkan } \\
\text { prinsip }\end{array}$ & $\begin{array}{l}\text { Siswa sulit dalam menerapkan prinsip yang telah } \\
\text { ia dapatkan dan sulit dalam menerapkannya } \\
\text { dalam menyelesaikan soal }\end{array}$ \\
\hline 33. & $\begin{array}{l}\text { Kesulitan dalam } \\
\text { menyelesaikan masalah } \\
\text { verbal }\end{array}$ & $\begin{array}{l}\text { Siswa sulit dalam meneyelesaikan soal- soal yang } \\
\text { verbal atau soal- soal cerita }\end{array}$ \\
\hline
\end{tabular}

Diadaptasi dari Cooney [1]

Selain perbedaan kemampuan matematika di dalam kelas, perbedaan lain juga harus menjadi perhatian yaitu tentang gender. Perbedaan gender bukan hanya berakibat pada perbedaan kemampuan dalam matematika, tetapi cara memperoleh pengetahuan matematika juga terkait dengan perbedaan gender $[11,13,14]$. Bias gender juga dapat terjadi dalam pembelajaran. Bias gender dalam pembelajaran akibat adanya stereotipe dan pembakuan gender dapat mempengaruhi individu belajar. Stereotip gender adalah kesan atau keyakinan tentang perilaku yang pantas untuk perempuan dan laki-laki [7]. Perbedaan perlakuan gender dapat mempengaruhi dan membentuk pengalaman. Pengalaman ini dapat terbawa dalam pembelajaran, berpikir, kemampuan dalam menganalisis tugas termasuk kesulitan yang dialami dalam menyelesaikan soal. Hal ini 
diperkuat dari hasil penelitian yang menyatakan bahwa adanya pengaruh gender baik itu dari segi berpikir, kemampuan penalaran dan komunikasi matematis, maupun dalam pemecahan masalah $[2,14]$. Oleh karena itu, kesulitan yang dialami siswa laki-laki dan siswa perempuan dalam menyelesaikan soal operasi hitung pembagian dapat berbeda pula.

Oleh karena itu, berdasarkan uraian di atas peneliti terdorong untuk mengetahui kesulitan belajar siswa berkemampuan matematika rendah dalam menyelesaikan soal operasi hitung pembagian berdasarkan gender khususnya di kelas IV karena kelas ini merupakan awal kelas tinggi di sekolah dasar, sehingga kesulitan tersebut tidak berlanjut di kelas V dan kelas VI. Sehubungan dengan itu, maka peneliti terdorong untuk meneliti lebih jauh tentang “Analisis Kesulitan Belajar Siswa Berkemampuan Matematika Rendah Berdasarkan Gender".

\section{METODE PENELITIAN}

Penelitian ini berjenis deskriptif kualiatif karena digunakan untuk mendeskripsikan secara rinci tentang kesulitan belajar siswa berkemampuan matematika rendah dalam menyelesaikan soal operasi hitung pembagian berdasarkan gender. Metode pengumpulan data pada penelitian ini adalah tes penyelesaian operasi hitung pembagian dan wawancara. Subjek dalam penelitian ini adalah 1 siswa perempuan dan 1 siswa laki-laki SDN Bugih 1 Pamekasan kelas IV-A yang berkemampuan matematika rendah. Untuk menenjukan subjek penelitian ini menggunakan nilai Ulangan Akhir Semester (UAS) dimana nilai UAS dari subjek penelitian masuk dalam kategori rendah $(0 \leq$ nilai tes $<65)$. Pada awalnya penelitian ini menggunakan instrumen tes kemampuan matematika (TKM). TKM adalah soal-soal UN SD 3 tahun terakhir yang dimodifikasi menjadi soal uraian tentang materi yang telah ditempuh sebelumnya oleh siswa untuk mengukur tingkat kemampuan matematika siswa. Akan tetapi karena terjadi pandemi, peneliti merubah instrumen tes kemampuan matematika menjadi nilai Ulangan Akhir Semester dikarenakan peneliti tidak bisa melaksanakan tes kepada seluruh siswa kelas IV-A di SDN Bugih 1 Pamekasan secara bersamaan. Subjek terpilih selanjutnya diberi tes penyelesaian operasi hitung pembagian untuk mengetahui kesulitan belajar siswa. Jawaban siswa dianalisis berdasarkan indikator kesulitan belajar siswa. Untuk mengecek keabsahan temuan dalam penelitian ini, digunakan triangulasi waktu. Tes dan wawancara tentang TPS-OHP 1 dilaksanakan dalam waktu yang berbeda dengan tes dan wawancara tentang TPS-OHP 2. Rentang waktu yang dilakukan dalam penelitian ini yaitu 7 hari. Hasil tes dan wawancara dari TPS-OHP 1 dibandingkan dengan hasil tes dan wawancara dari TPS-OHP 2. Jika diperoleh kecenderungan yang sama maka pengumpulan data terhadap subjek penelitian tersebut selesai dan dapat ditarik kesimpulan. Akan tetapi, jika memiliki kecenderungan yang berbeda, maka akan dilakukan tes dan wawancara TPSOHP secara berulang-ulang sampai diperoleh data yang valid.

Berikut adalah soal tes penyelesaian operasi hitung pembagian yang digunakan dalam penelitian ini.

\section{Soal tes penyelesaian operasi hitung pembagian 1:}

1. a) $42: 6=\ldots$

b) $72: 8=\ldots$

2. a) $357: 17=\ldots$

b) $746: 14=\ldots$ sisanya $\ldots$.

3. a) Seorang pedagang mempunyai $875 \mathrm{~kg}$ terigu yang dimasukan ke dalam $5 \mathrm{karung}$ terigu. Jika setiap karung berisi terigu yang sama beratnya, berapa kg berat terigu pada setiap karung? 
b) Seorang pedagang buah-buahan memesan $225 \mathrm{~kg}$ jeruk. Jeruk tersebut akan dimasukan ke dalam 4 keranjang sama banyak. Berapa kg jeruk dalam setiap keranjang dan berapa sisanya?

\section{Soal tes penyelesaian operasi hitung pembagian 2:}

1. a) $54: 6=\ldots$

b) $64: 8=\ldots$

2. a) $450: 18=\ldots$

b) $548: 9=\ldots$ sisanya $\ldots$.

3. a) Nina menabung di sekolah setiap hari sama banyak. Dalam waktu 30 hari jumlah uang tabungan Nina 75.000 rupiah. Berapa rupiahkah Nina menabung setiap hari?

b) Pedagang mempunyai $356 \mathrm{~kg}$ minyak kelapa. Minyak kelapa tersebut dimasukan ke dalam 9 kaleng. Berapa kg minyak kelapa dalam setiap kaleng dan berapa $\mathrm{kg}$ sisanya?

\section{HASIL DAN PEMBAHASAN}

Berdasarkan data nilai UAS siswa, diperoleh 2 siswa perempuan dan 3 siswa lakilaki yang nilainya berada pada kategori kemampuan rendah $(0 \leq$ nilai tes $<65)$. Adapun siswa yang dijadikan subjek penelitian dalam penelitian adalah 1 siswa perempuan (S1) dan 1 siswa laki-laki (S2). Alasan peneliti memilih subjek tersebut, adalah : 1) kesesuaian kategori tingkat kemampuan rendah, 2) memiliki kemampuan komunikasi yang baik berdasarkan informasi dari guru, dan 3) bersedia untuk diberikan tes penyelesaian operasi hitung pembagian dan diwawancarai.

Berikut adalah hasil dan pembahasan tes penyelesaian operasi hitung pembagian dan wawancara yang diperoleh peneliti terhadap subjek perempuan (S1) :

Pada indikator kesulitan dalam mempelajari konsep, subjek mengerjakan soal operasi hitung pembagian tidak berdasarkan konsep pembagian. Subjek mengerjakannya dengan cara mengurangi bilangan yang dibagi dengan pembagi. Melakukan pengurangan satu kali saja. Padahal nilai yang dibagi masih bersisa dan sisa tersebut belum bernilai 0 atau kurang dari nilai pembagi. Akan tetapi subjek memahami bahwa konsep pembagian adalah kebalikan dari perkalian. Namun hanya untuk bilangan dengan nilai yang kecil saja. Ketika nilai bilangannya besar, subjek belum mampu menyelesaikannya. Berikut hasil pekerjaan dan wawancara subjek terkait indikator kesulitan dalam mempelajari konsep.

1a) $42: 6=386 \quad 1 \times 7=72 \times 7=14$
b) $72: 8=64$

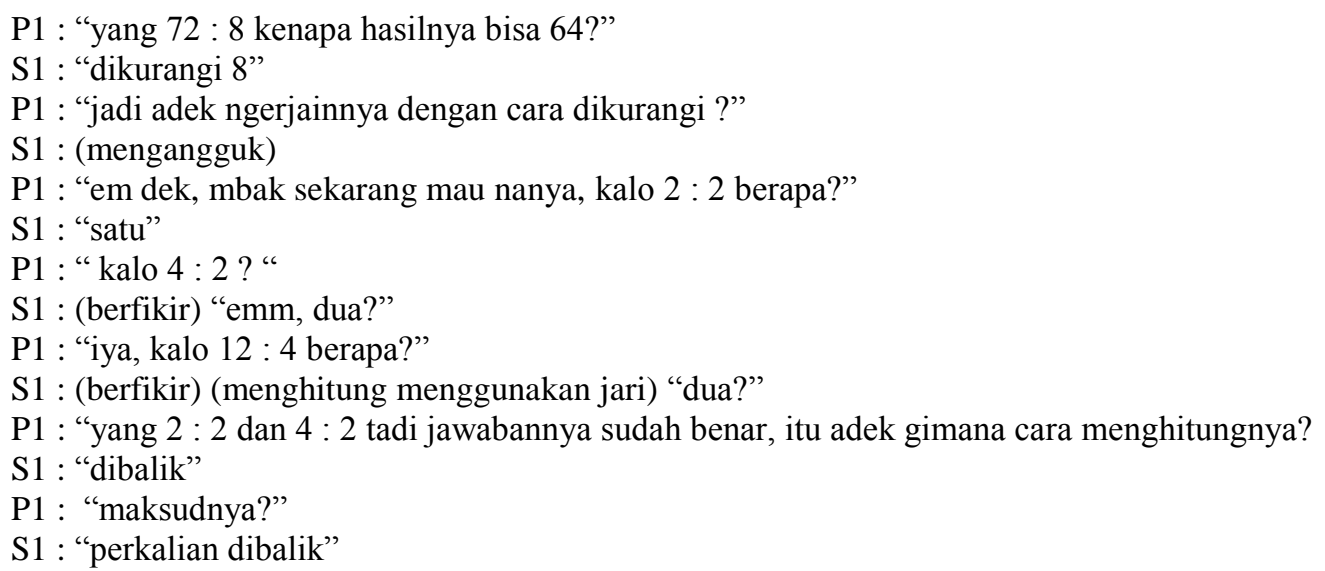




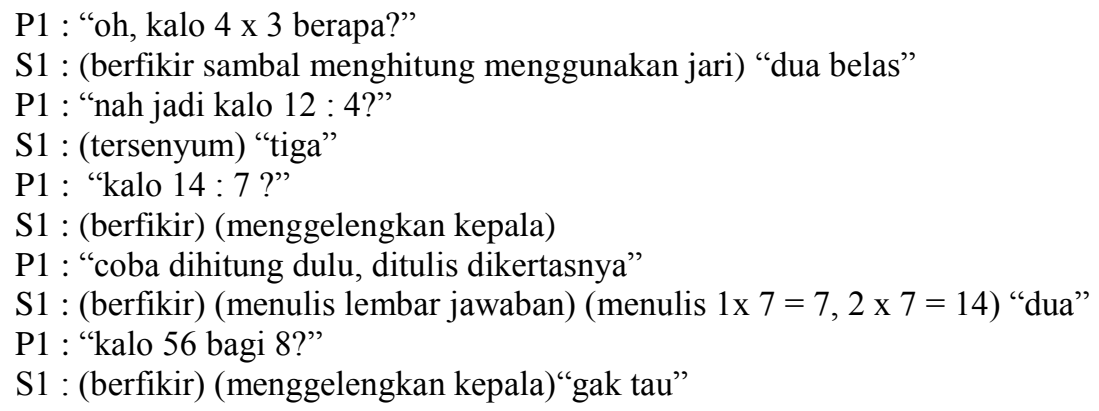

Pada indikator kesulitan dalam menerapkan prinsip, subjek tidak mampu mengerjakan pembagian bersusun dengan benar karena subjek tidak mampu menerapkan prinsip pembagian pada pembagian bersusun. Subjek tidak tahu jika bilangan yang dibagi harus dikurangi sampai sisanya 0 atau kurang dari nilai pembagi. Subjek tidak tahu menuliskan hasil dari pembagian bersusun tersebut.. Berikut hasil pekerjaan dan wawancara subjek terkait indikator kesulitan dalam menerapkan prinsip.
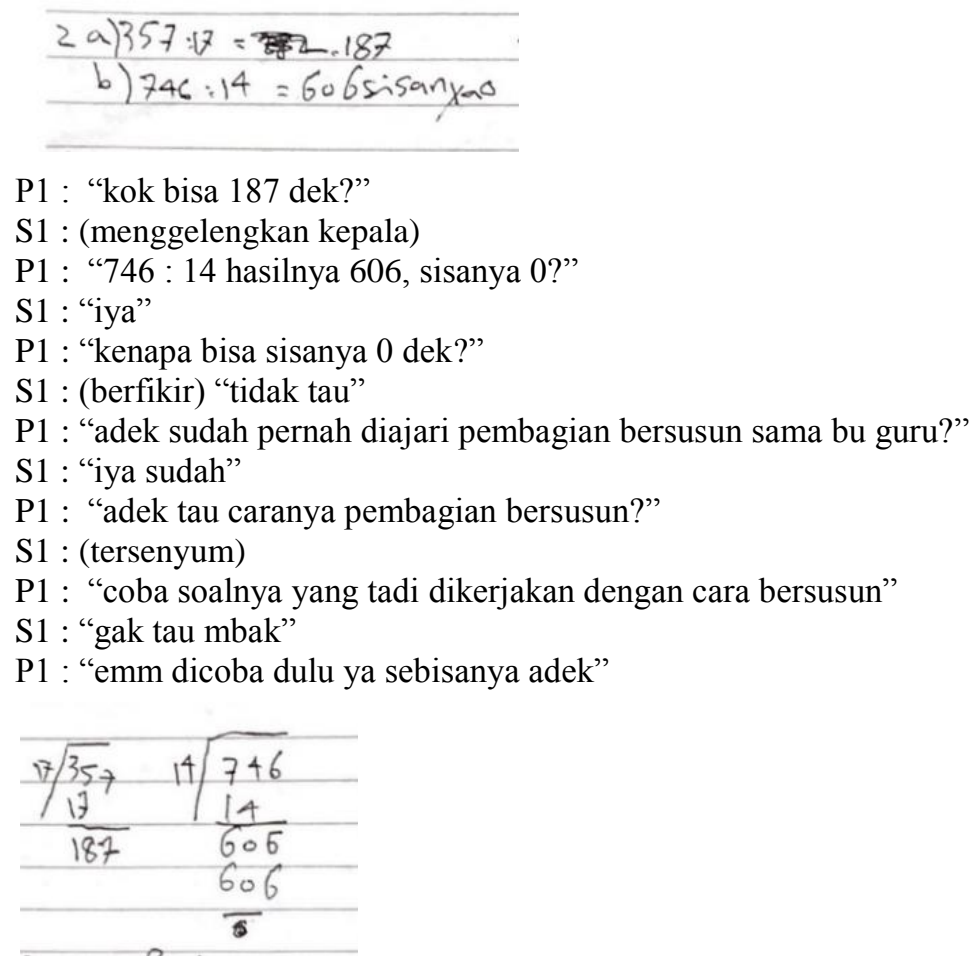

P1 : "coba di jelasin langkah-langkah yang point a ini dek"

S1 : "em 357 dikurangi 17 187"

P1 : "kalo yang b?"

S1 : "746 dikurangi 14, 606 dikurangi sama dengan 0"

Pada indikator kesulitan dalam menyelesaikan masalah, subjek tidak mampu menuliskan terlebih dahulu apa yang diketahui dan apa yang ditanyakan dari soal cerita dengan tepat. Ketika diminta untuk menuliskan apa yang diketahui dan apa yang ditanyakan, subjek menuliskan kembali soal cerita tersebut. Subjek tidak mampu mengatur proses pengerjaan dengan baik, masih kurang teliti dalam mengerjakan dan masih cenderung mengerjakan soal dengan cara menebak-nebak jawaban. Berikut hasil pekerjaan dan wawancara subjek terkait indikator kesulitan dalam menyelesaikan masalah.

3 a) 375
b) 18


P1 : “dek, untuk yang a ini, 45.000 dapat dari mana dek?

S1 : (tersenyum) (menunjuk ke soal) "ini sama ini” (menunjuk ke bilangan 75.000 dan bilangan 30)

P1 : "diapain dek?"

S1 : (tersenyum) "gak tau mbak"

P1 : "em, dikurangi apa dibagi dek?"

S1 : (menatap) "dibagi"

P1 : "75.000 dibagi 30 sama dengan 45.000?"

S1 : (mengangguk)

P1 : "em, kalo yang b gimana caranya?"

S1 : "sama"

P1 : "iya dek, sama gimana?"

S1 : "ini sama ini mbak" (menunjuk ke bilangan 356 dan bilangan 9"

P1 : "dikurangi atau dibagi juga?"

$\mathrm{S} 1$ : (berfikir) "em dibagi juga?"

P1 : "hasilnya 366?"

S1 : "iya"

P1 : "em oke sekarang gini, mbak minta yang nomer 3 adek jawab ulang ya. Ditulis dulu apa yang diketahui sama apa yang ditanya di soal ini, trus abis itu baru ditulis jawabannya ya"

S1 : (mengangguk) (menulis dilembar jawaban)

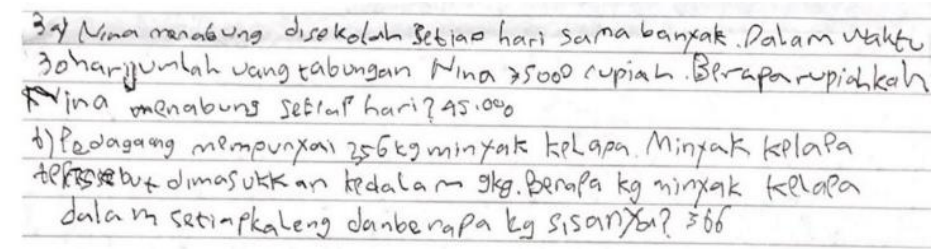

P1 : "adek paham yang mbak minta?"

S1 : "iya" (menulis)

P1 : "ditulis dulu apa yang diketahui sama yang ditanyakan dari soal ini, baru adek tulis jawabannya adek"

S1 : (mengangguk)

Berdasarkan hasil penelitian relevan menyimpulkan bahwa siswa berkemampuan matematika rendah masih mengalami kesulitan menentukan konsep, menerapkan prinsip dan keterampilan. Siswa juga tidak teliti dalam membaca soal sehingga belum mampu membuat model dari soal cerita yang diberikan dan belum mampu untuk menyelesaikan soal yang diberikan [4]. Hasil penelitian di atas sejalan dengan hasil penelitian ini bahwa kesulitan belajar subjek penelitian S1 dalam menyelesaikan soal operasi hitung pembagian. Dimana subjek penelitian S1 mengalami kesulitan dalam mempelajari konsep, menerapkan prinsip, dan menyelesaikan masalah verbal. Subjek penelitian S1 belum mampu menuliskan apa yang diketahui dan apa yang ditanyakan dalam soal cerita yang diberikan. Sehingga S1 belum mampu mengerjakan penyelesaian soal tersebut dengan benar.

Selain itu, hasil penelitian lain menyimpulkan bahwa siswa perempuan mengalami kesulitan dalam memahami konsep, mengalami kesulitan dalam menentukan operasi pengerjaan seperti penjumlahan, pengurangan, perkalian, dan pembagian [3]. Hasil penelitian tersebut juga sejalan dengan hasil penelitian ini bahwa kesulitan belajar subjek penelitian S1 yang merupakan siswa perempuan. Subjek penelitian S1 mengalami kesulitan dalam memahami konsep pembagian yang merupakan pengurangan berulang 
sampai bersisa 0 atau kurang dari nilai pembagi. Selain itu, S1 juga mengalami kesulitan dalam menentuka operasi pengerjaan seperti pengurangan, perkalian, dan pembagian.

Berikutnya adalah hasil dan pembahasan tes penyelesaian operasi hitung pembagian dan wawancara yang diperoleh peneliti terhadap subjek laki-laki (S2) :

Pada indikator kesulitan dalam mempelajari konsep, subjek belum memahami konsep pembagian adalah pengurangan berulang. Pemahaman subjek yaitu bahwa pembagian hanya dikurangi satu kali saja padahal konsep pembagian itu merupakan pengurangan berulang sampai bersisa 0 atau lebih kecil dari angka pembagi. Akan tetapi, pengurangan yang dilakukan subjek hasilnya masih belum tepat. Ketika subjek diberikan soal pembagian dengan bilangan yang nilainya kecil sekalipun, subjek belum mampu menjawabnya dengan benar. Subjek cenderung menjawabnya dengan cara menebaknebak jawaban. Berikut hasil pekerjaan dan wawancara subjek terkait indikator kesulitan dalam mempelajari konsep.

a) $42: 6=12$

b) $72,8=46$

P1 : "42 : $6=12$ ya dek? dapet dari?"

S2 : "dari 42"

P1 : "digimanain 42nya dek?"

S2 : "dikurangi"

P1 : "dikurangi brapa?"

S2 : "42 dikurangi 6"

P1 : "hasilnya 12 ?

S2 : (mengangguk)

P1 : "dikurangi satu kali?"

S2: (diam)

P1 : "dikurangi 6 nya satu kali dek?"

$\mathrm{S} 2:($ diam $)$

P1 : "42 kan dikurangi 6 ya dek? Adek ngerjainnya gitu?"

S2: "ga tau"

P1 : "oh adek nulis 12 aja gitu?"

S2 : (mengangguk)

P1 : "kalo yang $72: 8$ dek? gimana caranya?

S2 : "72 dikurangi 8"

P1 : "oh iya. sekarang mbak nanya ya dek, kalo 2 x 2 brapa dek?

S2 : "delapan"

$\begin{array}{rr}2 \times z=8 & 14 \\ 3 \times 2=8 & z: 1=1 \\ 4 \times 2=12 & 3: 2=1 \\ 1: 1=1 \\ 4: 2=2\end{array}$

P1 : "kalo 3 x 2 dek?"

S2: "delapan"

P1 : "coba 4 x 2"

P1 : "em. Oke, sekarang mbak mau nanya lagi, kalo $2: 1$ brapa dek?"

S2 : "satu"

P1 : "kalo $3: 2$ dek?"

S2: (menulis 1$)$

P1 : "em kalo $1: 1$ ?"

S2 : (menulis) "satu"

P1 : "coba $4: 2$ "

$\mathrm{S} 2$ : (menulis 2$)$ "dua"

P1 : "gimana ini caranya $4: 2$ kok bisa 2 dek?"

S2 : "empat" 


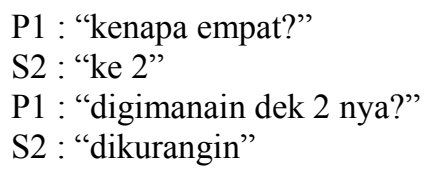

Pada indikator kesulitan dalam menerapkan prinsip, subjek tidak mampu mengerjakan operasi pembagian bersusun dengan tepat karena subjek belum mampu menerapkan prinsip pembagian pada pembagian bersusun. Subjek mengerjakannya dengan cara mengurangi bilangan yang dibagi dengan pembagi. Akan tetapi, hasil pengurangannya tidak tepat. Selain itu, subjek juga tidak menuliskan hasil dari pembagian tersebut. Berikut hasil wawancara dengan subjek terkait indikator kesulitan dalam menerapkan prinsip.

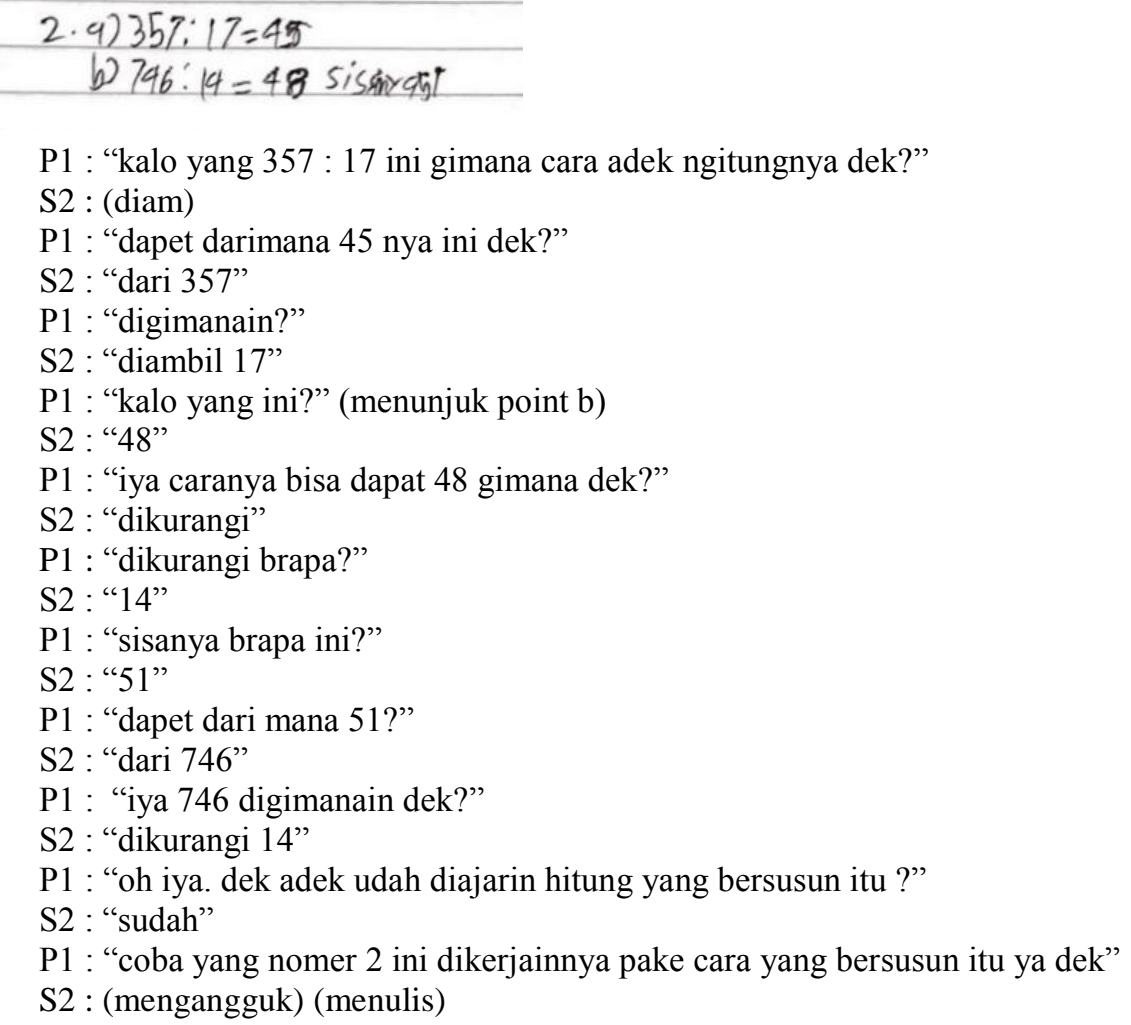

$\frac{357}{\frac{17}{282}:}$
$\frac{65}{85}=\frac{746}{14}:$
$\frac{\frac{7}{31}}{14}=$
$2 \times 2=8$

P1 : "357 dibagi 17?"

S2 : "iya mbak"

P1 : "hasilnya ini?" (menunjuk bilangan 82)

S2 : "iya mbak"

P1 : "ini brapa dek? 65?"

S2 : "05 mbak"

P1 : "oh, dari?"

S2 : "dari 82 mbak"

P1 : "82 digimanain?"

S2 : "dikurangi mbak" 


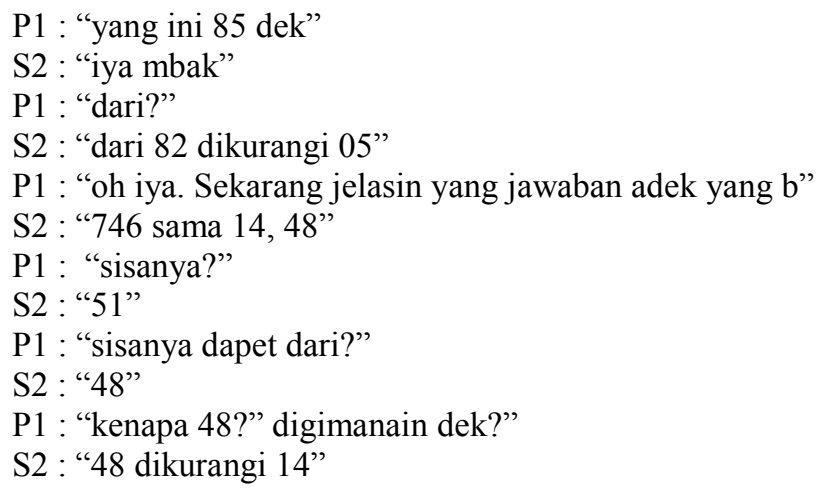

Pada indikator kesulitan dalam menyelesaikan masalah, subjek tidak mampu menuliskan apa yang diketahui dan apa yang ditanyakan dari soal cerita dengan tepat. Ketika subjek diminta untuk menuliskan apa yang diketahui dan apa yang ditanyakan, subjek hanya menuliskan bilangan-bilangan yang tercantum pada soal cerita yang diberikan tanpa menuliskan satuannya atau keterangan dari bilangan tersebut. Subjek belum mampu mengatur proses pengerjaan dengan baik, masih kurang teliti dalam mengerjakan dan masih cenderung mengerjakan soal dengan cara menebak-nebak jawaban. Berikut hasil wawancara dengan subjek terkait indikator kesulitan dalam menyelesaikan masalah.

\section{$3+4$ d $\quad b 491$}
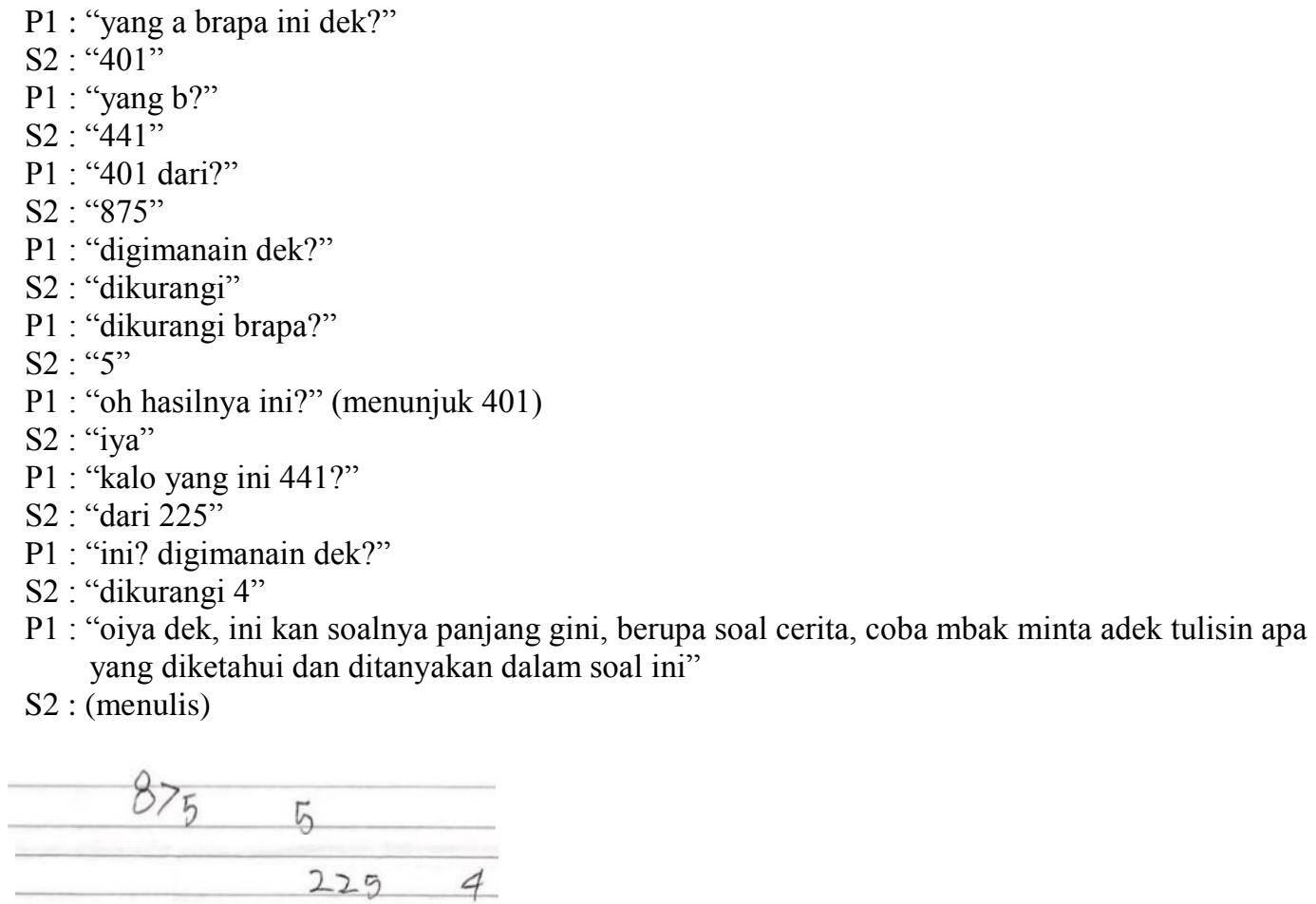

P1 : "yang a ini apa yang yang diketahui dek?"

S2 : "875"

P1 : "apalagi?"

S2 : "5"

P1 : "kalo yang ditanya apa dek?"

S2 : " 875 "

P1 : "itu yang ditanya?" 


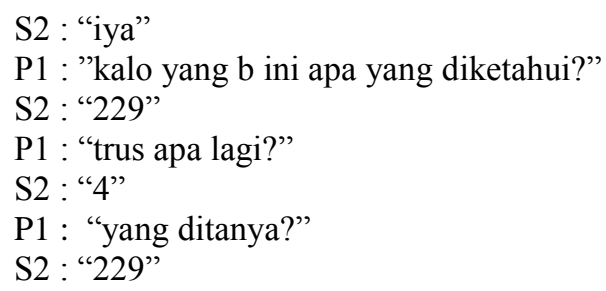

Hasil penelitian kesulitan belajar S2 dalam menyelesaikan soal operasi hitung pembagian sesuai dengan hasil penelitian yang menyatakan siswa berkemampuan rendah hanya mampu menyelesaikan 1 soal saja atau tidak sama sekali [9]. Dengan kata lain bahwa siswa dengan tingkat koneksi matematis rendah mengalami kesulitan cenderung ketiga dari indikatornya atau hanya dua indikator kesulitan. Kaitan antara penelitian [9] dengan hasil penelitian kesulitan belajar subjek penelitian S2 dalam menyelesaikan soal operasi hitung pembagian adalah bahwa S2 belum mampu menyelesaikan soal yang diberikan sama sekali. S2 mengalami kesulitan cenderung ketiga dari indikator kesulitan belajar siswa dalam menyelesaikan masalah yaitu kesulitan dalam memahami konsep, kesulitan dalam menerapkan prinsip, dan kesulitan dalam menyelesaikan masalah verbal.

Selain itu, hasil penelitian lain juga menyimpulkan bahwa siswa laki-laki mengalami kesulitan dalam memahami soal sehingga kurang tepat dalam menyelesaikan hasil akhirnya [3]. Hasil penelitian tersebut sejalan dengan hasil penelitian kesulitan belajar subjek penelitian S2 yang merupakan siswa laki-laki. Dari hasil penelitian, menunjukkan bahwa S2 mengalami kesulitan dalam memahami soal yang operasi hitung pembagian khususnya pada soal operasi hitung pembagian berbentuk soal cerita. Hal ini berakibat pada hasil akhir yang diperoleh kurang tepat.

Terlihat bahwa kedua subjek mengalami kesulitan belajar dalam menyelesaikan soal operasi hitung pembagian. Pada indikator kesulitan dalam memahami konsep, hasil penelitian kesulitan belajar subjek perempuan (S1) dan subjek laki-laki (S2) dalam menyelesaikan soal operasi hitung pembagian yaitu kedua subjek tidak tahu konsep pembagian sebagai pengurangan berulang. Pada indikator kesulitan dalam menerapkan prinsip, kedua subjek tidak mampu mengerjakan pembagian bersusun dengan benar karena kedua subjek tidak mampu menerapkan prinsip pembagian pada pembagian bersusun. Sedangkan pada indikator kesulitan dalam menyelesaikan masalah verbal, kedua subjek tidak mampu menuliskan terlebih dahulu apa yang diketahui dan apa yang ditanyakan dari soal cerita dengan tepat.

Adapun kelemahan pada penelitian ini yaitu (1) Tes Penyelesaian Operasi Hitung Pembagian (TPS-OHP) yang digunakan kurang mewakili permasalahan operasi hitung pembagian yang ada karena hanya terdiri dari beberapa soal saja, sehingga untuk penelitian selanjutnya diharapkan materi yang digunakan dapat mewakili materi matematika yang cakupannya lebih luas; (2) Subjek yang digunakan dalam penelitian ini hanya dilakukan pada tingkat satuan pendidikan SD. Sehingga hasil yang didapat mungkin akan menimbulkan perbedaan apabila dilakukan pada tingkat satuan yang berbeda.

\section{KESIMPULAN}

Berdasarkan hasil analisis data yang telah diuraikan di atas, menunjukkan bahwa pada indikator kesulitan dalam memahami konsep, hasil penelitian kesulitan belajar subjek perempuan (S1) dan subjek laki-laki (S2) berkemampuan matematika rendah dalam menyelesaikan soal operasi hitung pembagian yaitu kedua subjek tidak tahu konsep pembagian sebagai pengurangan berulang. Pada indikator kesulitan dalam menerapkan prinsip, kedua subjek tidak mampu mengerjakan pembagian bersusun 
dengan benar karena kedua subjek tidak mampu menerapkan prinsip pembagian pada pembagian bersusun tersebut. Sedangkan pada indikator kesulitan dalam menyelesaikan masalah verbal, kedua subjek tidak mampu menuliskan terlebih dahulu apa yang diketahui dan apa yang ditanyakan dari soal cerita dengan tepat.

Saran yang dapat peneliti kemukakan yaitu: (1) Hasil penelitian dan temuantemuannya dapat dijadikan pijakan untuk penelitian lanjutan; (2) Hasil penelitian dan temuan-temuannya dapat dijadikan sebagai informasi kepada guru matematika untuk lebih banyak memberikan penanaman konsep dan memperbanyak frekuensi latihan soalsoal matematika khususnya pokok bahasan operasi hitung pembagian sehingga dapat mengatasi kesulitan yang siswa alami dalam menyelesaikan soal-soal tersebut.

\section{DAFTAR PUSTAKA}

[1] Abdurrahman, M. (2003). Pendidikan Bagi Anak Berkesulitan Belajar. Jakarta: PT. Rineka Cipta.

[2] Aini, S.D. \& Hasanah, S.I. (2019). Berpikir Visual dan Memecahkan Masalah: Apakah Berbeda Berdasarkan Gender? JNPM (Jurnal Nasional Pendidikan Matematika), 3(2), 177-190. doi: 10.33603/jnpm.v3i2.2192.

[3] Aminah, dkk. (2018). Analisis Kesulitan Siswa Dalam Menyelesaikan Soal Cerita Matematika Topik Pecahan Ditinjau Dari Gender. Jurnal Teori dan Aplikasi Matematika, 2 (2), 118-122. doi: 10.31764/jtam.v2i2.713.

[4] Dwidarti, dkk . (2019). Analisis Kesulitan Siswa Dalam Menyelesaikan Soal Cerita pada Materi Himpunan. Jurnal Cendekia: Jurnal Pendidikan Matematika, 3 (2), 315-322. doi: 10.31004/cendekia.v3i2.110.

[5] Misu, L., Hasnawati, \& Rahim, U. (2018). Analysis of Mathematical Ability Based on Gender. IOP Conf. Series: Journal of Physics: Conf. Series 1188 (2019) 012054, 1-5. doi:10.1088/1742-6596/1188/1/012054

[6] Ratumanan, G.T. dan Laurens, T. (2011). Evaluasi Hasil Belajar pada Tingkat Satuan Pendidikan. Surabaya: UNESA University Press.

[7] Santrock, J. W. (2009). Psikologi Pendidikan 3. Jakarta: Salemba Humanika.

[8] Syaiful, et all. 2019. Communication Skills and Mathematical Problem Solving Ability Among Junior High Schools Students Through Problem-Based Learning. International Journal of Scientific \& Technology Research (IJSTR), 8(11): 10481060. http://www.ijstr.org/final-print/nov2019/Communication-Skills-AndMathematical-Problem-Solving-Ability-Among-Junior-High-Schools-StudentsThrough-Problem-based-Learning.pdf

[9] Sholekah, dkk. (2017). Analisis Kesulitan Siswa Dalam Menyelesaikan Soal Matematika Ditinjau Dari Koneksi Matematis Materi Limit Fungsi. Jurnal UST Jogja, 1 (2): 151-164. doi: 10.30738/wa.v1i2.1413

[10] Soehardi Sigit. (2003). Esensi Perilaku Organisasi. Yogyakarta: Lukman Offset.

[11] Susento. (2006). Mekanisme Interaksi Antara Pengalaman Kultural-Matematis, Proses Kognitif, dan Topangan dalam Revensi Terbimbing (Disertasi Tidak Dipublikasikan). Universitas Negeri Surabaya.

[12] Wahyu, K. (2014). Developing conceptual understanding on division of fraction through multiple models (disertasi tidak dipublikasikan). Universitas Negeri Surabaya.

[13] Lanya, H., Zayyadi, M., Sulfiah, S. K., \& Roziq, A. (2021). Students' Mathematical Literacy on The Performance of PISA Questions: What Is Gender Correlation?. Jurnal Didaktik Matematika, 8(2), 222-234. 
[14] Lanya, H., Zayyadi, M., \& Aini, S. D. (2020). Mathematic Communication Skills In Senior High School Based On Gender Differences. Pi: Mathematics Education Journal, 3(2), 75-81.

[15] Zayyadi, M., \& Subaidi, A. (2018). Berpikir Kritis Mahasiswa dalam Memecahkan Masalah Aljabar. Paedagoria: Jurnal Kajian, Penelitian dan Pengembangan Kependidikan, 8(2), 10-15.

[16] Zahroh, H., Hafidah, H., Dhofir, D., \& Zayyadi, M. (2020). Gerakan Literasi Matematika dalam Peningkatan Kemampuan Pemecahan Masalah Matematis Siswa. Delta-Pi: Jurnal Matematika dan Pendidikan Matematika, 9(2). 